\title{
Metoda DEA w pomiarze efektywności pracowników biur rachunkowych
}

\author{
Maria Lisiecka | Wydział Zarządzania, Uniwersytet Gdański
}

Słowa kluczowe: pomiar efektywności, księgowi, biura rachunkowe

\section{Streszczenie}

W literaturze spotyka się wiele metod pomiaru efektywności pracownika, większość z nich skupia się jednak na ilościowym charakterze pracy. W odpowiedzi na poszukiwania dogodnej metody analizy efektywności pracowników, których praca ma charakter jakościowy, udało się ustalić, iż metodą taką jest metoda DEA. Na podstawie ankiety i badania grupy księgowych ukazany zostanie schemat analizy efektywności podobnych rodzajowo pracowników. Przedstawione wnioskowanie bazuje na autorskim badaniu ankietowym opisującym ocenę własną pracy każdego badanego. Celem analizy jest uzasadnienie wyboru metody DEA i ukazanie jej możliwości względem pomiaru efektywności reprezentantów grupy pracowników umysłowych. Zagadnienie mierzenia efektywności pracowników biur rachunkowych oraz próba wskazania cech jednostek efektywnych pozwoliły dodatkowo na wydzielenie cech stymulujących efektywność. Wnioski wskazują, że kontrola efektywności pracowników biur rachunkowych jest możliwa. Po zapoznaniu się z wynikami można zauważyć, że metoda DEA jest dobrą metodą do analizy efektywności pracowników umysłowych w skali przedsiębiorstwa lub grup pracowników.

\section{DEA Method in Measuring the Efficiency of the Accountancy Offices Employees}

\section{Abstract}

Keywords:

In the literature there are many methods of measuring the effectiveness of an employee. However the majority of them focuses on the quantitative nature of the work and evaluate it in this sense. In response to the search for a convenient method of analysis of the effectiveness of employees, whose work is qualitative, it has been determined that usage of a method DEA is recommended. Mostly because its measurement should allow the recognition of efficiency in a qualitative way. Based on a study of groups of the accountancy offices from Tricity, an effectiveness scheme analysis of generically similar employees is presented. The inference is based on a innovative survey, which allows evaluation of work for each employee in the sample. The aim of the analysis is the justification for the choice of the DEA method. It is also to show its opportunities with respect to measuring the effectiveness of the accountancy offices employees, as representatives of a group whose work is difficult to measure. The issue of measuring the effectiveness of the accountancy offices encouraged an attempt to identify the characteristics of effective units, which could help to stimulate efficiency features. The conclusions are potentially desirable from the point of view of the employer and could help in the verification at the level of recruitment. 


\section{Wstęp}

Według Paula A. Samuelsona i Williama D. Nordhausa „Efektywność jest jednym z głównych przedmiotów, a być może głównym przedmiotem, zainteresowania ekonomii" (2004: 185). Jest kluczowym czynnikiem decydującym o powodzeniu wielu działań w gospodarce. Efektywność pracownika jest natomiast jedną z bardziej pożądanych przez pracodawcę cech; jest to podstawowa kategoria, która podlega ocenie w ramach badania kondycji pracowników. Istnieje wiele metod pomiaru efektywności, większość z nich skupia się jednak na ilościowym charakterze pracy i ten aspekt poddaje ocenie. W literaturze szeroko opisane jest zastosowanie metody DEA jako dogodnej metody analizy efektywności pracowników, których praca ma charakter jakościowy i której pomiar powinien pozwalać na ujęcie efektywności także w sposób jakościowy. Jednak brakuje badań pracowników biur rachunkowych jako pracowników o wysokiej specyfikacji pracy, którą trudno określić w sposób mierzalny. W oparciu o ankietę i badanie grupy pracowników biur rachunkowych z Trójmiasta ukazany zostanie schemat analizy efektywności podobnych kategorii pracowników. Do konstrukcji rankingu pracowników efektywnych wykorzystana została metoda DEA. Przedstawione wnioskowanie bazuje na autorskim badaniu ankietowym opisującym ocenę własną pracy każdego badanego pracownika poprzez nowatorsko ujęte nakłady i rezultaty pracy.

Celem badania jest podjęcie próby skonstruowania wskaźnika efektywności dla pomiaru pracy pracowników, który to wskaźnik umożliwi wstępne typowanie najlepszego pracownika. Hipoteza badawcza stanowi zaś, że dzięki cechom wskaźnika efektywności uzyskanego w badaniu metodą DEA jest możliwa konstrukcja wskaźnika efektywności pracy specjalnie dla pracowników biur rachunkowych. Podjęta została również próba wskazania cech jednostek efektywnych, potencjalnie pożądanych z punktu widzenia pracodawcy. Dodatkowym walorem badania jest wydzielenie cech stymulujących i warunkujących efektywność, pomocnych przy weryfikacji na poziomie rekrutacji.

\section{Metoda DEA}

Metoda DEA (Data Envelopment Analysis) jest narzędziem decyzyjnym opartym na ustalaniu relatywnego pomiaru efektywności badanych jednostek, wyniki analizy są subiektywne i zależne od wielu czynników. Prawdopodobnie należy ona do najpopularniejszych metod analizy efektywności tak jednostek, jak i całych organizacji biznesowych, stąd jej założenia zostaną omówione w sposób ogólny. Znana jest cała gama zastosowań tej metodologii analizy danych podczas pomiaru efektywności między innymi instytucji finansowych i ubezpieczeniowych, sektora publicznego (na przykład szpitali, szkół), gospodarstw rolnych i wielu innych jednostek organizacyjnych spełniających kryteria metody. Głównym powodem jej popularności jest 
umożliwienie pomiaru przypadków wcześniej niemierzalnych ze względu na kompleksową lub nieznaną naturę licznych nakładów i rezultatów (Cooper, Seiford, Tone 2007: xxiv).

Autorzy koncepcji DEA w postaci kanonicznej CCR (wykorzystanej w badaniu) to trójka amerykańskich naukowców - A.W. Charnes, William W. Cooper i E.L. Rhodes którzy w 1978 jako pierwsi, w pracy Measuring the Efficiency of Decision Making Units (Pomiar efektywności jednostek decyzyjnych [tłum. własne - M.L.]), zaproponowali nieparametryczną metodę analizy efektywności.

Na potrzeby DEA-CCR stosuje się głównie pojęcie efektywności w rozumieniu Farella-Debreu. Zgodnie z tą perspektywą efektywność jednostki ocenia się zawsze względem innych. Jeśli przy takich samych nakładach żadna inna jednostka nie osiąga lepszego rezultatu, mamy do czynienia z jednostką w pełni efektywną, jeśli natomiast rezultaty choć jednej innej jednostki przy tych samych nakładach są wyższe, jednostka przez nas badana jest nieefektywna. Głównym zastosowaniem metody obwiedni danych jest ułatwienie procesu decyzyjnego dotyczącego na przykład wyboru najefektywniejszej technologii, szpitala, strategii i tak dalej poprzez konstrukcję rankingów i wskaźników całkowitej efektywności technicznej, która opisuje efektywność jako konwertowanie nakładów w rezultaty (Ramanathan 2003: 78).

\section{Założenia i charakterystyka metody DEA}

Aby możliwe było zastosowanie tej metody niezbędne jest spełnienie kilku warunków:

- dysponujemy zbiorem obiektów $01, \ldots, O j$,

- yrj to wielkość rezultatów $r$-tego rodzaju w obiekcie j-tym,

- xnj to wielkość nakładu n-tego rodzaju w obiekcie j-tym (Guzik 2009: 27).

Inne założenia to między innymi (Guzik 2009: 28; Cooper, Seiford, Tone 2007: 22):

- jednorodny zbiór obiektów badanych,

- nieujemność nakładów i rezultatów,

- zgodności jednostek pomiaru,

- jednoznaczne wykazanie sytuacji korzystnej, na przykład opartej o zasadę gospodarności.

W większości sytuacji pomiar efektywności równoznaczny jest z przeprowadzeniem procesu decyzyjnego opartego na liniowym zadaniu mającym na celu znalezienie takiego optymalnego rozwiązania, które przy stałych nakładach pozwoli na maksymalizowanie efektów lub przy stałych rezultatach zapewni możliwość minimalizacji środków ponoszonych w celu ich uzyskania. 


\section{Kategorie nakładów i rezultatów w metodzie DEA}

W niniejszym badaniu efektywność i jej wskaźnik rozumiane są jako stosunek wyników (realizowanych celów i efektów końcowych) do nakładów (wykazywanych aktywności i czynności). Efekty, do których uzyskania dąży kadra przedsiębiorstwa, powinny jednocześnie spełniać cele indywidualne każdego pracownika, jak i stanowić rezultat pożądany dla całości przedsiębiorstwa. (Z zastrzeżeniem, iż suma celów indywidualnych nie musi być równa celowi przedsiębiorstwa). Ogólnie przyjętym wyznacznikiem rezultatów jest w skali firmy zysk lub strata, natomiast dla pojedynczego pracownika - wynagrodzenie. Niestety, ma to swoje znaczące ograniczenia w postaci niebezpośredniego odniesienia się do rzeczywistej efektywności. O ile na poziomie przedsiębiorstwa można wyznaczyć bezpośrednie nakłady działania, to w przypadku pracowników wynagrodzenie może być nakładem, jak i rezultatem, nie dając odpowiedzi na pytanie o kryteria efektywności. Ze względu na specyfikę branży, gdzie nie można zastosować innych pomiarów opartych na liczbie wyprodukowanych sztuk czy odbytych roboczogodzin i tak dalej, niezbędne jest, by na nowo zdefiniować nakłady i efekty z perspektywy pracownika, lecz takie, które można umieścić w całości instytucji zatrudniającej, w tym przypadku biura rachunkowego.

Dla zrealizowania tego postulatu wymagane jest zidentyfikowanie celów i możliwości księgowego. Jego praca wyceniana jest nie w sztukach towarów, lecz ewentualnie w liczbie poszczególnych typów obsługiwanych klientów oraz czasie ich obsługiwania. Takie zorientowanie ma wadę nie do zniwelowania, mianowicie każdy przypadek księgowy jest inny, a szybkość wykonania pracy nie zawsze jest miarodajna ze względu na późniejsze korekty. Należałoby rozpatrywać więc stosunek kosztów poniesionych w ciężar działalności na rzecz pracownika do jego bezpośredniego wkładu w przychody przedsiębiorstwa. To najbardziej logiczne odniesienie nie jest jednak bez wad. Przede wszystkim pomija całkowicie aspekty czynników jakościowych niezbędnych do badania efektywności pracowników umysłowych. Należy zwłaszcza z perspektywy przedsiębiorstwa nawiązać do koncepcji zarządzania i wyceny kapitału ludzkiego rozumianego jako umiejętności, możliwości, wiedza, zaangażowanie, doświadczenie i know-how pracowników wszystkich szczebli (Adamiec, Kożusznik 2000: 84). Modelowy schemat nakładów i rezultatów przyjmuje następującą postać: niech $x$ oznacza wektor autentycznych (empirycznych) nakładów obiektu, zaś y jego wektor rezultatów empirycznych. Ponadto $\tilde{x}$ oraz ỹ niech oznaczają wektory nakładów oraz rezultatów dowolnej technologii dopuszczalnej, czyli możliwej do zastosowania. Niech jeszcze $\theta$ oznacza cześć empiryczną nakładów obiektu $(0<\theta \leq 1)$, natomiast $\rho$ to wielokrotność rezultatów empirycznych $(\rho \geq 1)$ (Guzik 2009: 31).

\section{Schemat obliczeniowy metody DEA w ujęciu nakładowym}

Model CCR jest najstarszym i zasadniczo najpowszechniej stosowanym modelem Data Envelopment Analysis. Ma on charakter kanoniczny. Ideą oceny efektywności 
obiektu za pomocą modelu CCR jest ustalenie, czy w zbiorze technologii dopuszczalnych technologią najkorzystniej realizującą zadania badanego obiektu jest technologia tego właśnie obiektu. Wprowadzone pojęcie technologii w koncepcji DEA oznacza wektor empiryczny nakładów i rezultatów.

Do wyznaczenia technologii optymalnej potrzebna jest technologia wspólna. Jest ona ważoną sumą technologii poszczególnych obiektów. Aby uzyskać rozwiązanie w modelu CCR należy za pomocą liniowego równania wyznaczyć współczynnik $\lambda$ technologii. Współczynniki te, nazywane wagami intensywności, wskazują na stopień intensyfikacji uczestnictwa technologii empirycznej w technologii wspólnej o ukierunkowaniu na obiekt o-ty. Ustala się je w oparciu o zasady efektywności zależne od ukierunkowania (nakładkowe lub rezultatowe).

W ukierunkowaniu nakładowym celem, do którego realizacji dąży procedura CCR, jest minimalizacja tak zwanego mnożnika poziomu nakładów. Postulowanym zadaniem jest znalezienie takiej liczby nieujemnej:

$\theta_{o}-$ mnożnik nakładów obiektu,

$\lambda_{o j}$ - współczynnik kombinacji technologii wspólnej, która w modelu CCR jest też technologią optymalną obiektu o-tego,

ażeby: nakłady technologii wspólnej stanowiły możliwie najmniejszą część autentycznych nakładów tego obiektu, rezultaty technologii wspólnej były nie mniejsze od rezultatów rzeczywiście otrzymanych przez ten obiekt oraz określona technologia wspólna $T_{o}$ była dopuszczalna (Guzik 2009: 57).

Technologia wirtualnej (wspólnej) zbioru obiektów zorientowanej na obiekt o-ty przyjmuje postać:

$$
T_{o}=\Sigma_{j=1}^{\lrcorner} \lambda_{o j} t_{j}(1 \leq 0 \leq J) .
$$

Ustalona według CCR optymalna technologia wspólna zorientowana na obiekty o-ty jest technologią optymalną tego obiektu:

$$
\widehat{T}_{j}=\Sigma_{j=1}^{\lrcorner} \widehat{\lambda}_{o j} t_{j}(1 \leq O \leq J)
$$

(Guzik 2009: 38, 58).

\section{Efektywność pracowników biur rachunkowych}

Efektywność jest elementarną kategorią ekonomiczną. Jej szeroko rozpowszechnione użycie pozwala na utożsamianie tej kategorii z terminami takim jak racjonalność, skuteczność, produktywność, ekonomiczność, opłacalność, wydajność czy rentowność (Tyrańska 2009: 9). Zagadnienie pomiaru efektywności pracowników biur rachunkowych generuje dwa zasadnicze problemy badawcze. Pierwszym z nich jest kwestia ujęcia efektywności pracowników wykonujących zawiłą w kwantyfikacji aktywność. Kolejnym jest sposób ustalenia czynników pracy w przypadku nie tylko 
pracowników umysłowych, ale specyficznej podgrupy pracowników, których praca ma charakter wysoce zindywidualizowany i niezależny.

\section{Efektywność i wskaźnik jej pomiaru}

Opisany wcześniej wskaźnik efektywności uzyskany metodą DEA jest wskaźnikiem nieparametrycznym, który pozwala na określenie względnej efektywności wszystkich obiektów, ujmując ją jako stosunek wyników (zrealizowanych celów) do nakładów (wykazanych aktywności). W warunkach rynkowych, jeśli niemożliwe jest poprawienie/ulepszenie bez pogorszenia sytuacji innych zmiennych, sytuacja, jaka powstaje, nazwana została efektywnością Pareta (Varian 2005: 45). Choć początkowo koncepcja efektywności Pareta odnosiła się do poziomu całej gospodarki i alokacji oraz realokacji zasobów, koncepcja ta ewoluowała do poziomu pojedynczej jednostki - pracownika, firmy i tym podobnych. Poprzez rozwinięcie efektywności na poziomie efektywności technicznej możliwe było ujęcie promienia technologicznego, dlatego efektywność na potrzeby przeprowadzonego badania ujmuje się zgodnie z koncepcją Farella-Debreu, gdzie dzięki zastosowaniu skali ilorazowej możliwe jest wyrażanie względnej efektywności oraz zaprezentowanie indywidualnego stopnia sprawności czy odpowiednie grupowanie obiektów o podobnej lub różnej efektywności. Zgodnie z zasadą gospodarności zazwyczaj zakłada się ujęcie nakładowe, gdzie przy stałych (założonych) rezultatach dąży się do minimalizacji nakładów. W takiej interpretacji zakładamy, że istnieje jakiś założony i znany efekt, który stanowi $100 \%$ celu. Nie mając wpływu na cel, staramy się minimalizować nakłady tak, by bez ich marnotrawstwa osiągać wyznaczone efekty. Zbiór opcji minimalizacyjnych, sposobów wykorzystania nakładów nazywany jest technologią, w obrębie której mogą zachodzić zmiany nakładów. Wśród możliwych rozwiązań istnieją technologie dopuszczalne oraz jedna optymalna maksymalizująca efektywność poprzez zwiększenie stosunku efektów do nakładów. Wskaźnik efektywności skonstruowany w oparciu o powyższe założenia cechuje się tym, że jego wartość wzrasta wraz ze wzrostem efektywności oraz pozwala na konstrukcje rankingu obiektów, także istnieje przynajmniej jeden obiekt efektywny o wartości wskaźnika równej 1 (100\%).

\section{Nakłady i rezultaty pracy pracowników biur rachunkowych}

Wspominane wcześniej kategorie nakładów i rezultatów w większości badań poświęconych efektywności nie są tak problematyczne jak w przypadku niniejszego badania. Nakłady, jako element niezbędny pracy, umożliwiają osiąganie celów, tak że jeśli dla zwiększenia rezultatów należy zwiększyć jakiś czynnik, to jest on nakładem pracy. Zarówno nakłady, jak i rezultaty mogą mieć charakter liczbowy (finansowy) lub jakościowy (kategorie społeczno-kulturowe). Rezultaty pracy księgowego powinny być zbieżne z celami indywidualnymi pracownika oraz globalnymi zadaniami przedsiębiorstwa, tak by generować wartość nie tylko dla pracownika, lecz głównie dla 
przedsiębiorstwa. W badaniu wykorzystane zostały możliwości, jakie stwarza metoda DEA, użyto kilku nakładów i kilku rezultatów, ponieważ ujęcie tak kompleksowej działalności nie jest możliwe przy wykorzystaniu tylko jednego elementu po stronie nakładów i jednego rezultatu. Procedura wyboru elementów służących dalszym analizom była następująca: najpierw wyszczególniono czynniki nakładów i rezultatów, zaprezentowane w tabeli 1. Proces wyboru czynników oparto na schemacie poznania naukowego, wychodzącego od poznania faktów - realnych elementów pracy księgowego (Brzezinski, 2004: 34). Zostały one wyszczególnione na podstawie analizy pracy księgowego oraz literatury badającej zagadnienia badań społecznych i oceny pracowniczej. Następnie elementy te podzielono na nakłady i rezultaty, które kolejno stworzyły wielowymiarowe zmienne użyte w badaniu.

Tab. 1. Wybrane czynniki tworzące nakłady i rezultaty pracy księgowego

\begin{tabular}{|l|l|}
\hline \multicolumn{1}{|c|}{ Czynniki tworzące nakłady } & \multicolumn{1}{c|}{ Czynniki tworzące rezultaty } \\
\hline Wykształcenie & Realne szanse awansu \\
\hline Osobisty stosunek do pracy & Pochwały, premie, nagrody \\
\hline Stosunek do klientów & Chęć zmiany branży/pracy \\
\hline Odbyte kursy i szkolenia & Zadowolenie klientów \\
\hline Stabilność sytuacji rodzinnej & Rotacja klientów \\
\hline Satysfakcja z pracy/dalsza motywacja & Kary poniesione w rezultacie błędów pracownika \\
\hline Czas pracy/nadgodziny & Częstotliwość pomyłek \\
\hline
\end{tabular}

Źródło: opracowanie własne.

Ukazane wyżej w tablicy 1 czynniki pracy zostały użyte do konstrukcji zmiennych badania. Decyzja o selekcji kluczowych i potencjalnie istotnych zmiennych jest etapem teoretycznego konstruowania modelu według schematu Bunge’a oraz wnikliwej obserwacji elementów pracy księgowego'. Zmienne te mają charakter wielowymiarowy i szeroko dotykają poszczególnych aspektów pracy księgowego. Nie jest to bezpośrednie przełożenie konkretnych właściwości, ale odpowiedź na próbę segmentacji aktywności pracowników na kilka bloków, które zostały opisane w tablicy 2 wraz z uproszczonymi nazwami używanymi w dalszej części badania. Nakłady wyróżnione w badaniu po części stymulują do osiągania efektywności, po części zaś ją warunkują. W ramach nakładów pracy wyszczególnione zostały segmenty edukacja, stosunek do pracy oraz satysfakcja. Natomiast na rezultaty pracy składają się awans, klienci i pomyłki.

Efektywność pracy księgowego została oparta o sześć zmiennych, których ilościowe relacje, dzięki zastosowaniu metody DEA, pozwoliły na konstrukcję wskaźnika efektywności. Zgodnie z wcześniejszymi złożeniami liczba nakładów (trzy) oraz liczba rezultatów (trzy) umożliwiły odtworzenie kompleksowości pracy w biurze rachunkowym, a dzięki możliwościom metody DEA stworzony został jeden wskaźnik końcowy

\footnotetext{
${ }^{1}$ Na podstawie dokumentów regulujących pracę księgowego (ustawa z dnia 29 września 1994 r. o rachunkowości [tekst jedn.: Dz. U. 2016, poz. 1047, ze zm.] i innych dokumentów) oraz wywiadu z reprezentantami zawodu.
} 
Tab. 2. Wybrane czynniki tworzące nakłady i rezultaty pracy księgowego

\begin{tabular}{|l|l|}
\hline \multicolumn{1}{|c|}{ Rodzaj zmiennej } & Nazwa zmiennej \\
\hline \multicolumn{1}{|c|}{ Nakłady } \\
\hline $\begin{array}{l}\text { Posiadane wykształcenie i jego zgodność z obowiązkami, } \\
\text { uczestnictwo w kursach i szkoleniach }\end{array}$ & Edukacja \\
\hline Stosunek pracownika do pracy i obowiązków & Stosunek \\
\hline Motywacja do pracy, satysfakcja z pracy & Satysfakcja \\
\hline \multicolumn{2}{|c|}{ Rezultaty } \\
\hline Szanse awansu, pochwały, nagrody & Awans \\
\hline Zadowolenie klientów, częstotliwość ich rotacji & Klienci \\
\hline Częstotliwość pomyłek, kary & Pomyłki \\
\hline
\end{tabular}

Źródło: opracowanie własne.

analizy, tak zwany wskaźnik efektywności, obliczony zgodnie z przedstawioną formułą i omówiony w kolejnej części pracy.

\section{Badanie efektywności pracowników biur rachunkowych metodą DEA}

Specyfika pracy w biurze rachunkowym generuje wiele wyzwań w przypadku pomiaru efektywności pracy. Kolejnym z nich jest wysoce zindywidualizowany sposób wykonywania zadań, nie tylko ze względu na charakter pracownika i jego stylu pracy, programu, którego używa i tym podobne, ale również ze względu na różnorodność klientów i sposobów ich obsługi. Powyższe okoliczności są powodem, dla którego do przeprowadzenia pomiaru i analizy efektywności pracowników biur rachunkowych została użyta ocena własna obiektów, wyrażona poprzez odpowiedzi na pytania zawarte $w$ ankiecie. Wykorzystanie samooceny pracownika do weryfikacji jego efektywności ma swoje wady, między innymi barak ilościowego gruntu porównawczego czy rzeczywistej weryfikacji odniesionej w ciężar całości przedsiębiorstwa. Jednak by zrealizować cel tego opracowania, jest to możliwie najlepsza perspektywa badawcza. Przedstawione czynniki składowe nakładów i efektów podlegają zatem subiektywnej ocenie pracownika, niezależnie od stanu rzeczywistego systemu płac, opinii przełożonych, wykonywanych usług czy systemu organizacyjnego przedsiębiorstwa. Ankieta użyta do zebrania danych składała się z dziewiętnastu stwierdzeń, których zgodność i siłę tej zgodności ankietowany musiał wyrazić, zaznaczając odpowiedzi na pięciostopniowej skali Likerta, która umożliwia wszystkie operacje wykonane w dalszej części badania. Pytania, średnio po trzy, były przypisane do poszczególnych zmiennych i losowo umieszczone w ankiecie. Poza pytaniami o nakłady i rezultaty do ankiety dołączono pięć pytań kontrolnych o charakterystykę ankietowanego (wiek, płeć, staż pracy, sytuacje materialną i rodzinną), tak by możliwa była charakterystyka obiektów efektywnych i nieefektywnych. Dane zebrane zostały między styczniem a lutym 2012 roku, dotyczyły biur rachunkowych z terenu Trójmiasta oraz kilku innych miejscowości, w sumie badaniu podlegało 92 pracowników. Proces ankietyzacji uwzględniał pracowników biur rachunkowych, osoby pozostające w stosunku pracy w biurze rachunkowym na stanowiskach księgowych i niebędących 
właścicielami lub innym pracownikami administracyjnymi oraz niezwiązanymi z księgowością. Powyższe założenie stanowi podstawę gruntu porównawczego, jako że zgodnie z ustawą o rachunkowości sposoby wykonywania pracy księgowego są bardzo wyraźnie określone poprzez przepisy i normy.

\section{Przykład zastosowania metody DEA do pomiaru efektywności pracowników biur rachunkowych}

Pierwszym krokiem właściwej analizy danych zebranych w ramach badania ankietowego była analiza czynnikowa, poprzedzona badaniem stopnia korelacji miedzy czynnikami. W niniejszym badaniu do tego celu posłużyła analiza jednorodności skali $a$-Cronbacha oraz KMO. Indeks KMO (Kaiser-Meyer-Olkin), porównując cząstkowe współczynniki korelacji z dwuzmiennowymi współczynnikami korelacji, przyjmuje wartości od 0 do 1, gdzie 0 oznacza, że spodziewana redukcja będzie niewielka, więc stosowanie analizy czynnikowej nie ma sensu. Jest sens, gdy KMO jest większe od 0,5 (Ciecieląg, Pęczkowski 2011). Natomiast dla analizy rzetelności skali $a$-Cronbacha możliwe wartości plasują się od 0 do 1, przy czym pożądana jest wartość bliska 1. Wyniki analizy stopnia skorelowania zmiennych zmieszczono w tabeli 3.

Tab. 3. Wartości $a$-Cronbacha i indeksu KMO

\begin{tabular}{|l|c|c|}
\cline { 2 - 3 } \multicolumn{1}{c|}{} & KMO & $a$-Cronbach \\
\hline Suma & 0,6563229 & 0,6921629 \\
\hline Edukacja & 0,6511792 & 0,5371620 \\
\hline Stosunek & 0,5160538 & 0,3900806 \\
\hline Satysfakcja & 0,6044333 & 0,6945726 \\
\hline Awans & 0,5396960 & 0,4883433 \\
\hline Klienci & 0,4808711 & 0,3390344 \\
\hline Pomyłki & 0,5538413 & 0,4294465 \\
\hline
\end{tabular}

Źródło: opracowanie własne.

Wartości $a$-Cronbacha, które otrzymano dla wybranego zbioru zmiennych, spełniają minimalne wymagania dla przeprowadzenia analizy czynnikowej oraz są minimalnym potwierdzeniem o poprawności założeń teoretycznych modelu (suma dla modelu 0,69). Wartość KMO również umożliwia przeprowadzenie dalszych czynności. Po sprawdzeniu warunków formalnych przeprowadzenia analizy czynnikowej dla badania opisanego w niniejszej pracy oraz założeń o wielkości próby (dziesięciokrotność liczby czynników) możliwe jest wyodrębnienie głównych składowych niosących największy ładunek informacji. Niewątpliwą przewagą czynników nad wejściowymi zmiennymi jest to, że są one nieskorelowane i uszeregowane według procentu wyjaśnianej przez nie wariancji. Analiza czynnikowa dzieli całą wariancję $n$ zmiennych na $n$ addytywnych czynników (Aczel 2005: 907). Następny etapem jest policzenie wartości własnej (eigenvalue) czynnika, informującej o jego udziale w zmienności wariancji. 
Tab. 4. Wartości własne czynników

\begin{tabular}{|l|c|c|c|c|c|c|}
\cline { 2 - 7 } \multicolumn{1}{c|}{} & Edukacja & Stosunek & Satysfakcja & Awans & Klienci & Pomyłki \\
\hline eigen.val1 & 1,8003095 & 1,4262278 & 1,9772720 & 1,4840460 & 1,320548 & 1,4567282 \\
\hline eigen.val2 & 0,9653727 & 0,9461804 & 0,7037192 & 0,9231085 & 1,014476 & 0,8971093 \\
\hline
\end{tabular}

Źródło: opracowanie własne.

Wartości własne czynników są do siebie zbliżone i oscylują między 1,3-1,9. Wskazuje to - według kryterium Keisera - na zbliżone znaczenie poszczególnych czynników dla wyjaśnienia przedmiotu badania. Aby potwierdzić znaczenie czynników, policzony został procent wariancji wyjaśniany przez czynnik.

Tab. 5. Wielkości wyjaśnianej wariancji

\begin{tabular}{|l|c|c|c|c|c|c|}
\cline { 2 - 7 } \multicolumn{1}{c|}{} & Edukacja & Stosunek & Satysfakcja & Awans & Klienci & Pomyłki \\
\hline \% of variance1 & 45,00774 & 47,54093 & 65,90907 & 49,46820 & 44,01828 & 48,55761 \\
\hline \% of variance2 & 24,13432 & 31,53935 & 23,45731 & 30,77028 & 33,81586 & 29,90364 \\
\hline
\end{tabular}

Źródło: opracowanie własne.

Wyniki analizy procentowego wyjaśnienia wariacji pozwalają na przyjęcie założenia o zbliżonym i równie istotnym wpływie każdego z dwunastu czynników na zmienność efektywności pracowników biur rachunkowych. Jednak aby nie zawężać możliwości badania oraz dla lepszego wyjaśnienia wariacji, każda ze zmiennych - poza zmienną "Klienci" - została wyrażona poprzez dwa czynniki główne, nazwane kolejno "Edukacja 1", „Edukacja 2" i tak dalej. Następnie wskutek rotacji ortogonalnej otrzymujemy ładunki czynnikowe dla każdego czynnika oraz każdego ankietowanego. Tabela 5 zawiera dwanaście czynników głównych, jednak analiza oparta będzie o jedenaście: sześć nakładów oraz pięć rezultatów. Ze względu na wymagania dotyczące informacji poddawanych analizie metodą obwiedni danych cały zbiór ładunków czynnikowych został poddany metodzie unifikacji zerowanej, a wartości dotyczące czynników „Pomyłki 1" i „Pomyłki 2" zostały uznane jako demotywujące i odpowiednio przekształcone.

Wartości ładunków czynnikowych otrzymane w wyniku przeprowadzenia analizy czynnikowej i po transpozycji metodą unifikacji zerowanej dzięki potwierdzeniu ilości nakładów i rezultatów posłużyły w dalszej części do dokonania analizy efektywności pracowników biur rachunkowych za pomocą metody obwiedni danych (DEA). Efektywność pracowników biur rachunkowych mierzona metodą DEA zakwalifikowana została jako badanie przeprowadzane od strony nakładów, ponieważ rekrutując pracownika, to właśnie jego potencjalne nakłady możemy zweryfikować, z perspektywy przedsiębiorcy bardziej korzystna jest więc analiza nakładów. Badanie zostało zrealizowane zgodnie z formułą i schematem opisanym w pierwszej części opracowania. Obliczeń zaś dokonano w programach Excel i R. 


\section{Wyniki przeprowadzonego badania}

W rezultacie analizy efektywności, zgodnie z celem badania, każdy z 92 pracowników poddanych badaniu otrzymał przypisany mu wskaźnik efektywności, którego wartość mieściła się od 0 do 1 . Zgodnie z możliwościami, które wynikają z właściwości wskaźnika, obiekty zostały uszeregowane według jego wartości. Obiekty efektywne to obiekty, których wskaźnik przyjmuje wartość 1, pozostałe to obiekty, które nie wykorzystują swojego potencjału nakładowego w sposób optymalny, z definicji są więc nieefektywne. Jednak możliwa jest też inna interpretacja wskaźnika. Przy tych samych rezultatach jednostka z wynikiem 1 (100\%) uzyskuje miano najlepiej wykorzystującej zasoby nakładów, jej sprawność wynosi 100\%. Analogicznie jednostka ze wskaźnikiem o wartości 0,8 jest sprawna w $80 \%$. Wyniki dla jednostek poddanych badaniu zostały pogrupowane ze względu na wartości wskaźnika i zaprezentowane na rysunku 1.

Analizując przebadaną grupę pracowników, można stwierdzić, że 15,22\% z nich jest w pełni efektywnych. Metoda DEA nie stwarza możliwości dalszego szeregowania obiektów efektywnych, jako iż każdy spełnia warunki efektywności w równym stopniu. Natomiast pozostałe obiekty podzielono na segmenty, z których najliczniejszy, stanowiący $60,87 \%$ wszystkich obiektów, to grupa o wskaźniku efektywności zawartym między 0,5-0,6. Obiekty efektywne w granicach $90 \%$ do $60 \%$ stanowiły $14,13 \%$ badanej grupy. Za obiekty nieefektywne uznane zostały wszystkie, których wskaźnik efektywności przyjmował wartości poniżej 0,5. Grupa ta stanowiła 9,78\% przebadanych pracowników.

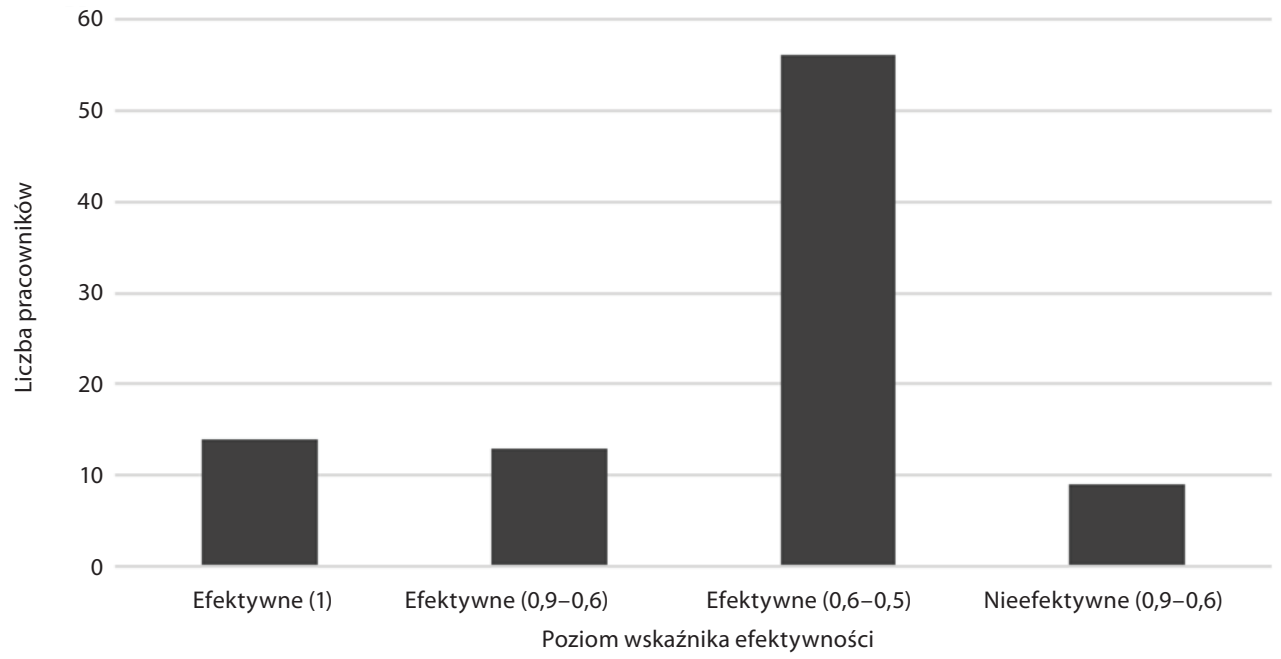

Rys. 1. Liczba pracowników biur rachunkowych podległych badaniu, ze względu na poziom sprawności, wyrażony wskaźnikiem efektywności

Źródło: opracowanie własne. 
Następnym krokiem analizowania otrzymanych wyników jest próba zestawienia średnich wartości odpowiedzi dla całości próby oraz tych samych średnich dla obu wyszczególnionych grup, to jest obiektów efektywnych i obiektów nieefektywnych. Jakkolwiek wartości całkowitoliczbowe przypisane poszczególnym wariantom odpowiedzi są jedynie kodami, w literaturze przedmiotu spotyka się próby wyznaczania na ich podstawie statystyk opisowych. Tablica 6 zawiera porównanie poszczególnych odpowiedzi na pytania, z uwzględnieniem zmiennej, której pytanie dotyczyło, oraz wyszczególnienie dwóch grup wśród pracowników ze względu na opisany wyżej wskaźnik efektywności, jak i różnice między wynikami obiektów efektywnych i pozostałych wyrażoną w procentach w stosunku do maksymalnej wartości odpowiedzi (5).

Tab. 6. Statystyki z odpowiedzi pracowników biur rachunkowych poddanych badaniu

\begin{tabular}{|c|c|c|c|c|c|c|}
\hline \multirow[t]{2}{*}{ Lp. } & \multirow[t]{2}{*}{ Pytanie } & \multirow[t]{2}{*}{$\begin{array}{c}\text { Cecha } \\
\text { przypisana }\end{array}$} & \multicolumn{3}{|c|}{$\begin{array}{l}\text { Średnie wartości dla } \\
\text { obiektów }\end{array}$} & \multirow{2}{*}{$\begin{array}{c}\Delta \text { efektywne- } \\
\text { nieefekywne } \\
\text { (w proc.) }\end{array}$} \\
\hline & & & $\begin{array}{c}\text { Wszyst- } \\
\text { kie }\end{array}$ & $\begin{array}{l}\text { Nieefek- } \\
\text { tywne }\end{array}$ & $\begin{array}{c}\text { Efektyw- } \\
\text { ne }\end{array}$ & \\
\hline 1. & Posiadam wykształcenie zgodne z moją pracą & Edukacja & 4,413 & 4,000 & 4,714 & 14,29 \\
\hline 2. & Uczestniczę w kursach i szkoleniach & Edukacja & 4,815 & 4,778 & 4,857 & 1,59 \\
\hline 3. & Ciągle się doskonalę & Edukacja & 4,174 & 4,000 & 4,429 & 8,57 \\
\hline 4. & Moje umiejętności są adekwatne do obowiązków & Edukacja & 4,174 & 4,444 & 4,643 & 3,97 \\
\hline 5. & Przykładam się do swoich obowiązków w pracy & Stosunek & 2,978 & 2,111 & 2,571 & 9,21 \\
\hline 6. & Nie obijam się w pracy & Stosunek & 4,457 & 4,556 & 4,071 & $-9,68$ \\
\hline 7. & $\begin{array}{l}\text { Mam pozytywne nastawienie do pracy; chętnie ją } \\
\text { podejmuje }\end{array}$ & Stosunek & 2,576 & 1,778 & 2,714 & 18,73 \\
\hline 8. & $\begin{array}{l}\text { Praca w tej organizacji jest dla mnie źródłem } \\
\text { satysfakcji }\end{array}$ & Satysfakcja & 2,913 & 2,333 & 3,000 & 13,33 \\
\hline 9. & Jestem zadowolony/ona z mojej pracy & Satysfakcja & 4,174 & 4,222 & 4,357 & 2,70 \\
\hline 10. & $\begin{array}{l}\text { W najbliższym czasie nie zamierzam zmieniać } \\
\text { pracy }\end{array}$ & Satysfakcja & 1,815 & 1,556 & 1,643 & 1,75 \\
\hline 11. & W najbliższym czasie mam szanse na awans & Awans & 4,228 & 4,111 & 4,143 & 0,63 \\
\hline 12. & $\begin{array}{l}\text { W najbliższym czasie mogę uzyskać większe } \\
\text { kompetencje }\end{array}$ & Awans & 3,978 & 4,111 & 3,714 & $-7,94$ \\
\hline 13. & Jakość efektów mojej pracy jest wysoka & Awans & 4,370 & 4,778 & 4,143 & $-12,70$ \\
\hline 14. & $\begin{array}{l}\text { Moi klienci sądzą, że solidnie wykonuję moją } \\
\text { pracę }\end{array}$ & Klienci & 2,076 & 2,222 & 2,214 & $-0,16$ \\
\hline 15. & $\begin{array}{l}\text { Często zdarza się, że klienci rezygnują z moich } \\
\text { usług }\end{array}$ & Klienci & 3,283 & 2,111 & 3,500 & 27,78 \\
\hline 16. & Obserwuje się dużą rotację moich klientów & Klienci & 3,185 & 3,444 & 2,929 & $-10,32$ \\
\hline 17. & Moja praca wymaga kontroli przełożonych & Pomyłki & 4,391 & 4,333 & 4,143 & $-3,81$ \\
\hline 18. & Błędy w wykonanej przeze mnie pracy są karane & Pomyłki & 4,130 & 3,778 & 4,143 & 7,30 \\
\hline 19. & Często popełniam błędy & Pomyłki & 2,141 & 1,667 & 2,000 & 6,67 \\
\hline I. & Wykształcenie: podstawowe/średnie/wyższe & & 2,630 & 2,778 & 2,786 & 0,16 \\
\hline II. & Wiek: 20-25/26-30/31-40/41-50/50 i więcej & & 2,902 & 3,556 & 2,714 & $-16,83$ \\
\hline III. & $\begin{array}{l}\text { Staż pracy w biurze rachunkowym: do roku/1-5/ } \\
5-10 / 10 \text { lat i więcej }\end{array}$ & & 2,620 & 2,889 & 2,500 & $-7,78$ \\
\hline IV. & Czy jestem głównym żywicielem rodziny? Tak/Nie & & 1,793 & 1,556 & 1,929 & 7,46 \\
\hline V. & Liczba dzieci na utrzymaniu: 0/1/2/3 i więcej & & 1,783 & 2,000 & 1,714 & $-5,71$ \\
\hline
\end{tabular}

Źródło: opracowanie własne. 
Na podstawie powyższej grafiki można wyraźnie zauważyć cechy różniące grupę obiektów efektywnych i nieefektywnych oraz różnice między nimi wyrażone w stosunku procentowym. Powyższe dane można szeroko interpretować. Jest to badanie opinii własnej pracowników, z tego powodu do bezpośredniej interpretacji danych niezbędne byłoby szersze spojrzenie socjologiczno-psychologiczne. Wiele wyników jest kontrowersyjnych z logicznej perspektywy, jednak jako wyniki badania jakościowego, uwzględniające element czynnika ludzkiego, powinny zostać traktowane relatywnie. Obiekty efektywne lepiej oceniły swoje przygotowanie zawodowe, a zwłaszcza adekwatność wykształcenia do zawodu. Pracownicy, którzy charakteryzują się najwyższym wskaźnikiem efektywności, posiadają o około 19\% bardziej pozytywne nastawienie do pracy. Wykazują też wyższy poziom satysfakcji $(+13,33 \%)$, wyrażony w pytaniu ósmym. Bardzo ciekawymi wynikami charakteryzują się natomiast dane opisujące rezultaty pracy obiektów. Pracownicy biur wyłonieni w ramach badania jako bardziej efektywni sami siebie oceniają jako mniej efektywnych, popełniających więcej błędów, są również o 13\% mniej zadowoleni z efektów swojej pracy. Jednak efekty ich pracy w mniejszym stopniu wymagają kontroli, a błędy przez nich popełniane są częściej karane. Analiza zmiennych kontrolnych jako obiekty efektywne wskazuje: osoby z wyższym wykształceniem (78\%), w wieku do trzydziestu lat (42\%), mające około pięciu lat stażu w biurze rachunkowym (50\%), niebędące głównym żywicielem rodziny (92\%; jest to cecha najbardziej jednorodna) oraz nieposiadające dzieci (65\%). Natomiast obiekty nieefektywne wskazane w ramach badania to: osoby ze średnim wykształceniem (23\%), osoby między trzydziestym a czterdziestym rokiem życia i starsze (67\%), posiadające staż pracy w biurze między pięć a dziesięć i więcej lat (78\%); 45\% osób wśród nieefektywnych jest głównymi żywicielami rodziny, ponadto $78 \%$ posiada jedno lub dwójkę dzieci.

Pośród cech badanych przez zmienne kontrolne można wyróżnić te najbardziej znaczące dla przyszłego pracodawcy. Najefektywniejsze są osoby młode, bezdzietne, posiadające dodatkowe źródło utrzymania i mające niewielki staż pracy. Spośród zmiennych determinujących efektywność wśród nakładów do najbardziej istotnych należą wykształcenie zgodne z zawodem, ciągłe doskonalenie się oraz pozytywny stosunek do pracy. Natomiast pośród rezultatów wskazane jest poczucie satysfakcji oraz świadomość karania błędów.

\section{Zakończenie}

Informacje uzyskane w ramach badania wymagają dalszej weryfikacji w ramach możliwości badania krzyżowego, jednak na ich podstawie (uwzględniając wszystkie ograniczenia badania) możliwe jest poznanie zagadnienia efektywności pracowników biur rachunkowych. Jest zatem możliwe ustalenie czynników pracy (nakładów i rezultatów) dla badania pracy pracowników umysłowych oraz stworzenie wskaźnika ich efektywności. Metoda DEA pozwala na tworzenie rankingów pracowników 
według stopnia ich efektywności oraz umożliwia przeanalizowanie grupy pracowników, których praca ma charakter jakościowy. Procedura badawcza jest stosunkowo łatwa do przeprowadzenia, pomimo wielu trudności wynikających ze specyfiki pracy w biurze rachunkowym. W ramach wybranej metody DEA, w modelu CCR istnieje możliwość operowania zarówno w obrębie wielu nakładów, jak i rezultatów, a czynniki badania nie muszą być wyrażone w środkach pieniężnych, ale mogą być zaprezentowane w swoich jednostkach naturalnych. Wyniki pracy opisane powyżej pozawalają na scharakteryzowanie potencjalnie efektywnego pracownika, tak by ułatwić pracodawcom dobór podczas rekrutacji. Zgodnie z wynikami badania wyróżnione zostały cechy potencjalnego pracownika determinujące jego efektywność. Do cech takich należą wykształcenie współmierne z zawodem, ciągłe doskonalenie się oraz pozytywny stosunek do pracy. Podczas pracy pożądane jest zaś poczucie satysfakcji oraz świadomość karania błędów, ponieważ zwiększa to efektywność pracowników.

\section{Literatura}

Aczel A.D., 2000, Statystyka w zarządzaniu. Pełny wykład, tłum. Z. Czerwiński, W. Latusek, Warszawa: Wydawnictwo Naukowe PWN.

Adamiec M., Kożusznik B., 2000, Zarządzanie zasobami ludzkimi, Kraków: AKADE.

Brzeziński J., 2004, Metodologia badań psychologicznych, Warszawa: Wydawnictwo Naukowe PWN. Ciecieląg J., Pęczkowski M., 2011, Analiza czynnikowa, Analiza głównych składowych, Warszawa: Wydział Nauk Ekonomicznych Uniwersytetu Warszawskiego.

Cooper W.W., Seiford L.M., Tone K., 2007, Data Envelopment Analysis: A Comprehensive Text with Models, Applications, References and DEA-Solver Software, New York: Springer.

Guzik B., 2009, Podstawowe modele DEA w badaniu efektywności gospodarczej i społecznej, Poznań: Wydawnictwo Uniwersytetu Ekonomicznego.

Samuelson P.A., Nordhaus W.D., 2004, Ekonomia, t. 1, tłum. Z. Wolińska, M. Rusiński, Warszawa: Wydawnictwo Naukowe PWN.

Tyrańska M., 2009, Jakość kapitału ludzkiego a efektywność przedsiębiorstwa, „Problemy Jakości”, nr 5.

Ramanathan R., 2003, An Introduction to Data Envelopment Analysis: A Tool for Performance Measurement, New Delhi: Sage Publications.

Varian H.R., 2005, Mikroekonomia. Kurs średni - ujęcie nowoczesne, tłum. S.R. Domański et al., Warszawa: Wydawnictwo Naukowe PWN.

Wieczorkowska G., Wierzbiński J., 2007, Statystyka. Analiza badan społecznych, Warszawa: Scholar. 